Nagy Péter

DOI: 10.15170/DIKE.2021.05.01.02

adjunktus

KRE ÁJK

\title{
A „per viam instantiae” perek az erdélyi református házassági jogban
}

\section{The „Per Viam Instantiae” Cases in the Matrimonial Law of the Reformed Church in Transylvania}

This article aims to analyse the "per viam instantiae" cases in the matrimonial jurisdiction of the Reformed Church in Transylvania. Until the introduction of civil marriages in 1895, denominations had the right to declare the marriage of their members in Transylvania in the second balf of the nineteenth century. All this time, in the motherland, these cases fell under the jurisdiction of civil courts, and the canon law did not recognise the dissolution of marriage. Therefore, it was easier to get divorced in Transylvania than in the otherparts of the Austro-Hungarian Empire. Due to this difference between the rules in the field of matrimonial law, the matrimonial courts of the protestant churches were the goal and an opportunity for the people who wanted to get divorced.

Keywords: marriage, private law, divorce, Transylvania, Reformed Church

\section{Bevezetés}

Erdélyben a házassági jog fejlődése más utat járt be, mint a Királyhágón innen. A polgári házasság bevezetéséig a házassági ügyekben való ítélkezés a különböző felekezetek joga maradt, világi bíróságok csak a vagyonjogi kérdésekben dönthettek. Minden felekezet a saját joga szerint itélkezett.

A vallásilag vegyes házasságok esetében a protestáns felekezetek között egy sajátos együttmúködés alakult ki, amely értelmében többségében elfogadták az alperes vallása szerint elsőként eljáró felekezet fórumának ítéletét. A római katolikus egyház azonban nem ismerte el a házasságok felbontását, ezért a 19. század második felében a házasságot felbontani kívánó fél, vagy felek egyre gyakrabban tértek át egy másik, a házasság felbontását elismerő vallásra. Erdély és Magyarország uniójának kimondását követően megnőtt azoknak az aránya is, akik a Királyhágón inneni országrészből ezzel a céllal erdélyi lakóhelyet és új vallást választottak. Az 1880-as években pedig már az Osztrák-Magyar Monarchia más részeiből is számos házaspár választotta ezt az utat.

Az erdélyi református egyházban a legfontosabb forrást Bod Péter 1763-ban kiadott Házassági törvény rajza jelentette, amelyet sosem fogadtak el törvényként, de minden keresetlevélben és ítéletben hivatkozták. Az erdélyi református házassági bíráskodás gyakorlata a következő száz évben átalakult, ezért az eltérések rögzítése és a gyakorlat egységesítése érdekében egy utasítás kiadása mellett döntött az erdélyi református Házassági Főtörvényszék, amelyet 1882ben fogadtak el. ${ }^{1} \mathrm{Ez}$ az utasítás szabályozta először az erdélyi református házassági bíráskodás

\footnotetext{
1 1.-1882. H. F. Sz. Utasítás a házassági válóügyek ellátására nézve az erdélyi evang. reform. egyházkerületben.
} 
legvitatottabb intézményét, a ,per viam instantiae” indított házassági ügyeket. ${ }^{2}$ Ez a szabályozás egyúttal a jogi lenyomatát is képezte az egykorú irodalomban az „erdélyi házasságnak” nevezett jelenségnek. A jelenkori társadalomtörténeti kutatások terminológiája szerinti a migrációs válások ${ }^{3}$ azonban nem csak a református egyházat érintették.

Jelen tanulmányban a migrációs válásokat lehetővé tevő erdélyi református egyházi szabályozást veszem górcső alá. A ,per viam instantiae” ügyek szabályozásának, eljárásának és az ehhez kapcsolódó álláspontok bemutatása előtt azonban két előkérdést szükséges röviden tisztázni. Az első a vonatkozó szakirodalom értékelése, a második pedig az „erdélyi házasság” fogalmának tisztázása.

A legkorábbi vonatkozó monográfia Wilhelm Fuchs Die sogenannten siebenbürgischen Ehen und andere Arten der Wiederverehelichung geschiedener österreichischer Katholiken című 1889-ben kiadott könyve volt, ${ }^{4}$ amely a mai napig meghatározó és megkerülhetetlen munka a témával foglalkozó kutatók számára. ${ }^{5}$ Ezt a könyvet egy éles vita előzte meg és követte is egyben, amelynek az 1880-as években a legfontosabb osztrák színtere a Juristische Blätter volt, ahol Wilhelm Fuchson kívül Leopold Pfaff, Szász. Domokos és Roszner Ervin is hozzászólt az indulatos vitához. A napilapok közül a Nene Freie Presse ${ }^{6}$ vagy a katolikus-arisztokratikus beállítottságú Vaterland is számos kapcsolódó tudósítást, véleménycikket közölt.

A polgári házasság ${ }^{7}$ bevezetését követő időszakban a migrációs válások és a mögöttük húzódó magánjogi kollízió nem volt önálló történeti kutatás tárgya, csupán egy-egy tanulmány jelent meg a témával kapcsolatban. Ausztriában az 1980-as évektől került a kutatások fókuszába, és elsősorban a doktori disszertációk foglalkoztak részletesebben a kérdéskörrel. Christa Pelikean 1981ben publikálta Aspekte der Geschicbte des Eherechtes in Österreich címú dolgozatát, közel két évtizeddel később Angela Apel szerzett fokozatot Die Siebenbürgischer und die Ungarischen Ehen címú munkájával, ${ }^{8}$ valamint Ulrike Harmat Ehe auf Widerruf? Der Konflikt um das Eherecht in Österreich 1919-1938 címü munkájával. ${ }^{9}$ Christian Neschwara 2012-ben publikálta Eherecht und „Scheinmigration” im 19. Jabrbundert: Siebenbürgische und ungarische, deutsche und Coburger Ehen ${ }^{10}$ címû tanulmányát.

Magyarországon 20. század elején főként az egykorú szabályozást és a kapcsolódó kérdéseket vizsgálták. A 21. században a téma társadalomtörténeti megközelítésű kutatásával Nagy Sándor foglalkozott, aki a magyar-erdélyi viszonyú kutatást az unitárius házassági bíráskodáson

\footnotetext{
${ }^{2}$ NAGY, Erdélyi református házassági bíráskodás 145-156.

3 A mai jogtörténeti szakirodalom a válás kifejezést az ágytól és asztaltól való elválasztás (separatio a thoro et mensa) esetén, míg a bontást a kötelék végleges megszűnése esetén használja. Mivel az Utasítás és a korabeli szakirodalom divortium esetén a végleges elválás kifejezést használja (1.-1882. H. F. Sz. Utasítás 2. §), ezért e tanulmány keretei között is ekként használom.

${ }^{4}$ FUCHS, Die sogenannten siebenbürgischen Ehen 188.

${ }^{5}$ A zürichi egyetem professzora Friedrich Meili munkájában külön szakaszban jelölte az erdélyi házasságokat (\$ 63.). MEILI, Geschichte und System des internationalen Privatrechts im Grundriss 71.

${ }^{6}$ Magyarországon is visszhangot keltô cikke volt például: Die siebenbürgischen Ehen 1-2.

${ }^{7}$ HerGER, A nővételtől az állami anyakönyvvezetőig 73-112.

8 PELIKAN, Aspekte der Geschichte des Eherechtes in Österreich; APEL, Die Siebenbürgiscer und die Ungarischen Ehehen. A munkákat idézi: NESCHWARA, Eherecht und „Scheinmigration” im 19. Jahrhundert 116-117.

${ }^{9}$ HARMAT, Ehe auf Widerruf? Der Konflikt um das Eherecht in Österreich 1919-1938. Idézi: NAGY, Osztrák válások Erdélyben, 1868-1895 361.

${ }^{10}$ NESCHWARA, Eherecht und „Scheinmigration” im 19. Jahrhundert 101-117.
} 
keresztül mutatta be, valamint elemezte az osztrák-erdélyi migrációs válásokkal is. ${ }^{11}$ Ezirányú kutatásainak eddigi eredményeit Österreichische Scheidungen in Klausenburg (1868-1895) Otto Wagners „Siebenbürger Ehe” című munkájában foglalta össze. ${ }^{12}$

A második fontos tisztázandó kérdés a „migrációs válás” vagy más néven „erdélyi válásnak” vagy „erdélyi házasságnak” nevezett jelenség meghatározása.

A migrációs válások olyan a házasság felbontására irányuló, bíróság előtt lefolytatott eljárások voltak, amelyek során a peres felek, vagy egyikük a vallásukat, lakóhelyüket megváltoztatták, vagy új állampolgárságot vettek fel annak érdekében, hogy az ügyükre vonatkozó joghatóság az általuk kedvezőbbnek tartottra megváltozzon. A 19. század második felében ezeket nevezték az Osztrák-Magyar Monarchiában „magyar”, „kolozsvári” vagy „erdélyi válásnak”. Ezzel a lehetőséggel főként a katolikus felekezethez tartozó házastársak éltek, mivel a protestánsok jellemzően helyben bontották fel házasságukat. ${ }^{13}$ A cél az új házasság lehetőségének kieszközlése volt, ezért nevezték az eljárást „erdélyi házasságnak.”. ${ }^{4}$

A migrációs válások között különbséget tehetünk abban a tekintetben, hogy rendelkezett-e nemzetközi elemmel, azaz, hogy nemzetközi magánjogi problémáról volt-e szó, vagy pedig ennek híján csupán a hazánkban ekkor felekezetenként eltérő házassági jogok közötti összeütközés alakította ki ezt a helyzetet. Nem csak az osztrák válások tartoztak előbbi kategóriába, hanem lényegében az 1867 előtt a Királyhágón inneni felek által kötött házasságok is.

\section{A „migrációs válások” és az erdélyi református házassági bíráskodás}

Nagy Sándor Budapesti válások - Kolozsváron (1869-1895) című tanulmányában az új házasságot kötő elvált személyekre vonatkozóan vizsgálta a budapesti protestáns házassági anyakönyvekben található bejegyzéseket. ${ }^{15}$ Arra a következtetésre jutott, hogy az erdélyi evangélikus törvényszéket 4, a reformátust 43, az unitáriust pedig 464 alkalommal ${ }^{16}$ jelöltek meg eljáró bíróságként. ${ }^{17}$

Hasonlóképp nagy számban választották a kolozsvári református és unitárius házassági törvénykező fórumokat azok az osztrák házaspárok, akik fel akarták bontani a házasságukat. A földrajzi adottságokból adódó jelentős útitávolságok és a költségek vállalása mögött meghúzódó motivációt a bontáson túl az új házasság megkötésének a reménye jelentette. Egy becslés szerint, amelynek segítségével egyúttal képet kaphatunk a jelenség mértékéról, „1879-ig 300 olyan házasságot kötöttek, amelyet osz̨trák felek magyarországi (erdébyi) bontóper nyomán kötöttek; ebböl mintegy 200 pár állitólag a császárvárosból származott”."

A „per viam instantiae” eljárásra akkor került sor, amikor egy nem protestáns vallású házaspár nem protestáns egyházi szentszéken, vagy polgári bíróság előtt kezdett perbe, és az ítélet

\footnotetext{
${ }^{11}$ NAGY, Osztrák válások Erdélyben, 1868-1895 359-428.; NAGY, Budapesti válások - Kolozsváron, 1869-1895 165.; NAGY, „Engesztelhetetlen gyűlölet” Válás Budapesten (1850-1914), 368-376.; NAGY, Egy birodalom, két állam, sokféle törvény 461-486.

${ }^{12}$ NAGY, Österreichische Scheidungen in Klausenburg (1868-1895) 75-158.

${ }^{13}$ NAGY, Budapesti válások - Kolozsváron, 1869-1895 176.

${ }^{14}$ NAGY, Osztrák válások Erdélyben, 1868-1895 360.

15 Amennyiben azok az előző házasságot felbontó bíróságra is megjegyzést tartalmaztak.

${ }^{16} \mathrm{Az}$ unitárius adatok esetén számos alkalommal nem budapesti vonatkozású volt.

${ }^{17}$ NAGY, Budapesti válások - Kolozsváron, 1869-1895 166.

${ }^{18}$ NAGY, Osztrák válások Erdélyben, 1868-1895 360.
} 
ideiglenesen vagy véglegesen ágytól és asztaltóli elválasztásra ítélte a feleket, ezt követően pedig a felek közül legalább az egyik áttért a református vallásra, és belépett az Erdélyi Református Egyházkerületbe. Ezáltal jogot szerzett arra, hogy az ottani házassági jog hatálya alatt kérje a házasság végleges felbontását. ${ }^{19}$

Az illető félnek a korábban felsorolt okmányok mellett csatolnia kellett még az áttérési bizonyítványt, valamint az arról szóló igazolást, hogy teljesítette azokat a kötelezettségeket, amelyek az egyháztagokat terhelték. Ezen kívül mellékelnie kellett a separatióról szóló eredeti ítéletet és az arra vonatkozó kérvényt, hogy a református egyházjog szerint mondják ki a divortiumot. ${ }^{20}$

„Perpetua-separatio” esetén azonnal ki lehetett mondani a házasság felbontását, ${ }^{21}$ amennyiben azonban „usque ad tempus separatiot” tartalmazott az ítélet, annak keltétől számított hat hónap elteltével volt megadható a házasság felbontása. ${ }^{22}$

Bár maga a jelenség nem volt újkeletű, az Utasítás novuma éppen abban állt, hogy szabályozta azokat az eseteket, amikor a separatio elkerülése érdekében a házasfelek vallást vagy lakóhelyet változtattak. Ez történhetett Erdélyen belüli felekezetváltással együtt, vagy úgy, hogy a magyarországi protestánsok ideiglenesen Erdélybe költöztek. Ezzel megváltozott a joghatóság, és lehetővé vált - vagy lényegesen könnyebb lett - a házasságok felbontása. A jellemző mégis az volt, hogy magyarországi vagy az osztrák örökös tartományokbeli lakosok költöztek a házasság bontása érdekében Erdélybe.

1855-ből maradt fenn egy levél Török Pál Nagy Péterrel folytatott levelezéséből, amelyben utóbbi részletes tájékoztatást ad a Kálvin téri gyülekezet lelkészének, és az egy ôt felkereső ügyvédnek, aki egy válni akaró, magyar honpolgársággal rendelkező pár ügyében fordult hozzá, hogy tájékoztassa az Erdélyben való elválasztás jogi tudnivalóiról. ${ }^{23}$ Eszerint „Mindezeket csak azért írom, hogy Ön átláthassa, miképp az érdeklett felek - ha valahol - itt Kolozsvárt érbetnek legkönnyebben célt; mivel még a közzsinat is ez évben éppen Kolozsvárt fog tartatni, $s$ ha az ügyvéd úr levelében irt utasitásomat követendik, még ez évben peröke végképp lejárbat. Erre néz̨ az̧ tanácslám, hogy az alperes rögtön jöjjön le s itt álljan át; az átállásra szülkééges idöt még egy már héttel megtoldván domicilialtnak tekinthetö; ekkoor a felperes, ki az̧alatt Magyarországon átállott, jöjö̈n személyesen; tartassan egy rendkivüli részletes zsinatot, melyen exmissiot nyerend; evvel felmehet, perét személyese által is folytathatván, s maga ott helyt sürgeti, eskeetésével a második rendes részletes zsinatig elkészülhet - mi junius 10-én lesz - itt végitéletet hoznak s megerösités végett a csakugyan június 17-én megkezdendö köz:sinat eleibe menend pere. Az átállás és perének lefolyta alatt folytonosan itt maradandó

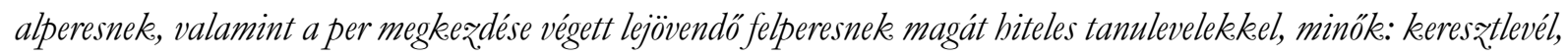
esketésröli bizonyitvány és a felperes részéröl átállásáróli bizonyitvány stb. stb. miket az ügyvéd urak jobban és pontosabban elösorolandnak - fel kell készülve lenni. Itt magoknak ügyvédet válasżtandnak és a felperes személyest is constitualand, s ha egyházi törvényeink szerint elegendố és hitelesen bebizonyitható ok van a válásra, isten segedelmével még ezév nyarán megszabadulnak egymástól. ${ }^{24}$

\footnotetext{
19 1.-1882. H. F. Sz. Utasítás, 73. §.

20 1.-1882. H. F. Sz. Utasítás, 74. \.

21 1.-1882. H. F. Sz. Utasítás, 75. \.

22 1.-1882. H. F. Sz. Utasítás, 76. \.

23 A levelet, melyet Nagy Sándor közölt monográfiájában, a téma szempontjából való jelentősége miatt egészében, változatlan formában közlöm.

${ }^{24}$ NAGY, „Engesztelhetetlen gyülölet” Válás Budapesten (1850-1914) 370.
} 
Jól tükrözi az effajta perek jellegzetességeit egy Barcza Kálmán által közölt és elemzett 1878as eset. A budapesti lakosú, katolikus házasfelek közül a nő férje ellen ágytól és asztaltól való elválasztás iránt pert indított az esztergomi főszentszék előtt 1873-ban, amelyet a négy évvel későbbi ítélet meg is adott. Az alperes férj fellebbezett, így az ügy másodfokon a prímási főszentszék, harmadfokon pedig az apostoli szentszék elé került. Mindkét fórum helybenhagyta az első fokon meghozott ítéletet. A harmadfokon eljáró bíróság a jogerôs ítéletét a feleknek 1878. április 24-én kézbesítette. A felperes Budapesten 1878. június 8-án áttért a református hitre, ezt követően pedig Kolozsváron „illetöséget esžközölt ki”, letette a polgári esküt, és felvétette magát a kolozsvári református egyház tagjai közé. Ezt követően a kolozsvári házassági törvényszékhez beadott egy kérvényt, miszerint az esztergomi főszentszék előtt lefolytatott perben ítélt ágytól és asztaltól való elválasztást változtassák végleges elválasztássá. Az erdélyi szabályok miatt ebben az esetben nem volt szükség bizonyítás lefolytatására, vagy az alperes jelenlétére, ezért a Házassági Főtörvényszék jogerôsen kimondta a divortiumot, a nő pedig 1878. június 17-én Gyôrben újabb (református) házasságot köthetett. ${ }^{25}$

Ez a helyzet azonban nem csak Magyarország és Erdély viszonyában állt fenn, hanem az Osztrák-Magyar Monarchia más területeivel is, amelynek egyik legfontosabb alapkérdése az állampolgárság volt. A szabadságharc leverésétôl a kiegyezésig az osztrák kormányhatóságok gyakorolták a legfőbb állami hatalmat, ennélfogva az állampolgárságot is ezek a hatóságok adományozták. A magyar állampolgárság megszerzésére azok a jogszabályok és szokásjogi normák voltak irányadók, amelyek 1848 előtt is érvényben voltak. Az állampolgárságot - a szabadságharcot és annak leverését követően is - csak a magyar szokásjogi normáknak megfelelően lehetett megszerezni. ${ }^{26}$

A kiegyezést követő időszakban nem létezett osztrák-magyar állampolgárság. Nem volt Magyarországnak és Ausztriának közös államterülete, mindkét államot megillette a saját területe feletti rendelkezési jog, és így az állampolgársági jog tartalmának meghatározása is. ${ }^{27}$ Ugyanakkor a magyar állampolgárság megszerzéséről és elvesztéséről szóló 1879. évi L. törvénycikk azt is rögzítette, hogy (az Erdéllyel kiegészült) „a magyar korona összes országaiban az állampolgárság egy és ugyanaz:"28

Rendkívül fontos, a gyakorlat által is megerősített szabály volt, hogy egy osztrák állampolgár csak akkor honosíthatta magát Magyarországon, ha előbb elbocsátották. Ezt a magyar hatóságok megkövetelték. ${ }^{29}$ Ugyanakkor kiemelendô, hogy a birodalmi állampolgárság gondolata mindvégig megmaradt, különös tekintettel az osztrák szakírók köreiben, azonban a monarchia két államának „állampolgársági jogi közelitése” a magyarok körében ütközött ellenállásba. A válási migráció szempontjából azonban jelentôs és egyben a helyzetet tovább bonyolító szabály volt, hogy az osztrák közjog Magyarország területét nem tekintette külföldnek. Az osztrák-magyar állampolgárság összeférhetőségének elve a Reichsgericht gyakorlatában is megjelent, a magyar

\footnotetext{
${ }^{25}$ BARCZA, Házassági jogeset 326.

26 VARGA, A magyar állampolgársági jog a 19. században 65.

27 VARGA, A magyar állampolgársági jog a 19. században 120.

28 1879. évi L. törvénycikk a magyar állampolgárság megszerzéséről és elvesztésérôl, 1. \.

${ }^{29}$ VARGA, A magyar állampolgársági jog a 19. században 138.
} 
állampolgárságot nem tekintette idegennek, azt az osztrák honossággal összeférhetőnek és egy személy által is birtokolhatónak tartotta. ${ }^{30}$

Jelentős kérdés volt az alkalmazandó jog meghatározása, illetve az ellentétes elvek miatt annak elfogadása. 1873-ban a Vallás- és Közoktatási Minisztérium leiratot intézett az Igazgatótanácshoz, amelyet - a püspökön keresztül - a Házassági Főtörvényszék tárgyalt meg végül. Az Olmützi Császári és Királyi Kerületi Törvényszék felkeresését továbbította a minisztérium, amely kimerítő indokolás mellett tájékoztatást kért az erdélyi református egyházkerület szabályairól: „Elégséges-é, ha idegen tartománybeli ember nébány hétig Erdélyben tartózkodva valamelyik erdélyi ref. egyházkö̈zség tagjává magát beiratja, hogy az által már képesitve s jogositva legyen az erdélyi ref. egyház házassági birósága elött való pert indítani és illetékességi jogot megnyerni??"Válasz nem maradt fenn a püspöki levelezésben, a közjegyzőnek adott utasításban azonban rögzítették, hogy az 1868. évi XLIII. és LIII. törvénycikkek egyértelműen leírják az ide vonatkozó szabályokat. ${ }^{31}$

1877-ben fontos elvi jelentôségű döntést hozott a bécsi főtörvényszék, amelyet az Erdélyi Protestáns Közlöny is ismertetett. Anton Trewani, währingi üveges és felesége Katharina megegyezéssel válópert indítottak, az illetékes bécsi törvényszék a házasfelek ágytól és asztaltól való elválasztását rendelte el. A feleség ezt követően magyar állampolgárságot szerzett, és - ahogyan a cikk szerzője fogalmazott - „a mi házassági törvénykerzesünk útján” magára nézve véglegesen elválasztották korábbi férjétől. Ezt követően Joachim Morgenstern orvosdoktorral házasságot kötött. A volt férj a második házassága miatt büntető feljelentést tett neje ellen a bécsi törvényszéknél, poligámiával vádolva azt. Az ügyészség rövid nyomozást követően ejtette a bigámia vádját, de az Osztrák Büntetôtörvénykönyv 507. \(2) alapján vádat emelt a nő ellen arra alapozva, hogy ,idegen országba távozuán, ott házassági szövetségre lépett, mely az osztrák törvények értelmében nem lett volna megköthetô”, amit 3-tól 6 hónapig terjedő „,nehéz börtönneP’ büntettek. Az elsőfokú törvényszék elutasította az ügyészi keresetet. A fellebbezést követően a főtörvényszék helybenhagyta az első fokon eljáró fórum ítéletét, mivel a nő nem idegen országba, hanem - a magyar polgárjog megszerzésével - „saját hazáajába távozua” kötött Magyarországon érvényes házasságot és ennélfogva nem tartozott az osztrák igazságszolgáltatás hatáskörébe. ${ }^{32}$

\section{Sztehlo Kornél és Kolosváry Sándor vitája}

A kialakult helyzetet és az ellentétes álláspontok közötti feszültségre remek példa Sztehlo Kornél és Kolosváry Sándor hírlapi vitája, amely 1886-ban, a migrációs válásokról szóló viták egyik kiemelkedő periódusában zajlott.

Szteblo Kornéla Pesti Napló 1886. január 16-i számában Azerdélyi házasságról címmel reflektált egy a folyóirat hasábjain osztrák válóperről szóló korábbi cikkre. ${ }^{33}$ Az ügy jelentősége abban állt, hogy az osztrák bíróság az erdélyi református Házassági Főtörvényszék által jogerôsen kimondott házasságot felbontó ítéletét nem vette figyelembe, a frigyet továbbra is fennállónak ítélte, és ebből

\footnotetext{
30 VARGA, A magyar állampolgársági jog a 19. században 137.

${ }^{31}$ EREL, A21. D Kizárólagos Házassági főtörvényszéki Jegyzőkönyvek. 1866-1885. 1873. 314. o. 302. p. Az erdélyi ev. ref. egyházkerület Marosvásárhelytt 1873. November 3-án 4-én 5-én 6-án 7-én 8-án 11-én 12-én tartott Házassági fötörvényszékének Jegyzőkönyve 12. ív, 302. p.

${ }^{32}$ Cím és szerző nélkül, Erdélyi Protestáns Közlöny, 480.

${ }^{33}$ SzTEHLO, Az erdélyi házasságról 1. Megjelent még: SzTEHLO Az erdélyi házasságról [Ügyvédek Lapja] 4.
} 
kifolyólag a második házasságot érvénytelennek tartotta. Sqtehlo a cikkre is alapozva érvelt amellett, hogy az osztrák katolikus házasság külföldön érvényesen nem bontható fel, még akkor sem, ha az érintett katolikus osztrák házasfél lakóhelyén felbontható lenne. Az említett esetben a házasság felbontása után, de az új házasság megkötése előtt, a felperes megszerezte a magyar honosságot, az viszont a visszaható hatály tilalmába ütközött. ${ }^{34}$ Érvelésében a bécsi legfelsőbb törvényszék is erre hivatkozott. Az osztrák polgári törvénykönyv a házasság felbontásánál kizárta a lex fori alkalmazását. ${ }^{35}$ A házasság felbontásánál az osztrák jog szerint az osztrák honpolgárra nézve a honosság, az Ausztriában lakó más állampolgárságú személyre nézve a lakhely joga volt az irányadó, tehát minden esetben az osztrák jog volt az alkalmazandó.

Az idegen jog csak akkor volt alkalmazható, ha az idegen a cselekmény elkövetésekor egyúttal külföldön is lakott. Satehlo felhívta a figyelmet arra, hogy „abszolút érvényü nemzetköz̨i magánjog nem léterike, s minden nép maga határozza meg saját törvényeiben, mennyiben tartja tiszteletben saját területén idegen ország törvényeit”. A magyar jog szerint is csak annyiban volt végrehajtható az osztrák bíróság ítélete, amennyiben az nem ütközött hazai törvény tilalmába. ${ }^{36}$ Azt Sztehlo is elismerte, hogy a magyarországi ítéleteket Ausztriában rendszeresen nem ismerik el, és azt a házasságot, amelyet itthon a király nevében felbontottak, azt Bécsben a császár nevében fennállónak ítélték. Ezt azonban csak a világi bíróságok ítéleteire érti.

Az osztrák bíróságok azonban rendszeresen kétségbe vonták, vagy nem ismerték el az erdélyi református házassági törvényszékek ítéleteit. 1886. február 2-án a Házassági Főtörvényszék rendkívüli ülésen tárgyalta a kialakult helyzetet. Az elnöki szerepet betöltő püspök beszédében úgy fogalmazott, hogy az erdélyi református házassági bíráskodás eljárása az 1882-es Utasításon alapul, ennek ellenére gyakran megtörtént, hogy az osztrák törvényszékek kétségbe vonták az erdélyi református ítéleteket, illetve nem is ismerik el azokat. Erre alapozva kérést intézett a Főtörvényszékhez, hogy jogaik védelmének érdekében követeljék az ítéletek érvényességének elismerését. Az ennek következtében született határozat rögzítette, hogy a konkrét esetekkel kapcsolatban tiltakozni kell a bécsi törvényszéknél, valamint felhívta az Igazgatótanács figyelmét arra, hogy intézzen felterjesztést a kormányhoz, annak érdekében, hogy tegye meg a szükséges intézkedéseket az osztrák miniszternél az erdélyi református egyház jogainak biztosítása érdekében. ${ }^{37}$

Sq̨tehlo cikkében leszögezte, hogy az erdélyi házassági bíróságok válópereikben saját egyházi törvényeiket alkalmazták, és azt pedig a felekezeti keretek között működő házassági bíróságoktól nem lehet elvárni, hogy ne a saját hitelveik szerint megalkotott egyházi joguk szerint bíráskodjanak.

\footnotetext{
34 OPTK 5. S.

35 OPTK 4. \. „A polgári törvények kötelezik azon országok minden állampolgárait, melyek számára kibirdettek. Az állampolgárok azon cseiekvények és ügyletekben is, melyeket az állam területén kivül vesznek elö, ezen törvényekhez kötve maradnak, a mennyiben ez. által vállalkozási személyes képességök korlátoltatikés a mennyiben ezen cselekvények és ügyleteknek egyszersmind ezen országokban is jogi következményeiknek kell lenni. [...]”; 34. S. „Az idegeneknek jogügyletekre való személyes képességét rendszerint azon belynek törvényei szerint kell megitélni, melyeknek az idegen lakásánál, vagy, ha tulajdonképi lakása nincs, sqületésénél fogva, mint alattvaló alá van vetve; a mennyiben egyes esetekre nézve a törvényben más nem rendeltetik."”

36 1881. évi LX. törvénycikk a végrehajtási eljárásról, 4. \,Az osztrák-magyar monarchia másik államában bozott birói határozat és kötött egyezség alapján ezen állam biróságainak megkeeresésére, a végrehajtás a viszonosság elöföltétele alatt, feltétlenül elrendelendö, kivéve azon esetet, ha azon teljesitmény, mely végrehajtás utján érvényesittetni szándékoltatik, hazai tiltó törvénybe ütközilk." ${ }^{37}$ ERREL, A21. D. D9. A Házassági Főtörvényszék Jegyzőkönyve 1885-1895. 1886. febr. 2. 16.
} 
Az igazi problémát a szerző azonban abban látta, hogy ezek az ítélkezési fórumok - véleménye szerint - a hatáskörükre és az illetőségre vonatkozó szabályaikat saját maguk állapították meg. ${ }^{38}$

Az erdélyi református és az unitárius egyházak különbséget tettek azon válóperek között, melyekben egy másik fórum korábban ágytól és asztaltól való elválasztást nem ítélt meg, és a „per viam instantiae" indított perek között, ahol az ágytól és asztaltól való elválasztásra ítéleték a feleket.

A rendes válóperekben a református egyház joga szerint az alperes lakhelye szerinti illetékes bíróság járt el. Az egyoldalú folyamodással indítható ügyekben - Sztehlo szerint - a reformátusoknál csak azt kellett bebizonyítania a kérelmezőnek, hogy melyik egyház kötelékében teljesítette azokat a kötelességeket, amelyek minden felekezethez tartozóra nézve kötelezők voltak. Az ilyen egyoldalú folyamodás alapján indított válóperekben, „a házassági kötelék szentsége a legbotrányosabb módon sértetik meg, mert a házasság minden kotradiktorius eljárás mellózesével az ellenfél meghallgatása nélkül, elöre kialk.udott magas dijért bontatik fel, az idézett egyházi törvények biróságaik illetékességét a világ bármely részében lakó egyénre kiterjesztetike, csak azt szabván föltételïl, hogy az illetö valamely hatóságuk alatt lévö egyházkeözség tagjai közé beiratkozzéke és ott az egybári adó egy részletét lefizesse".

Sztehlo Kornél, aki a fiával, Szteblo Aladár ügyvédjelölttel ügyvédi irodájában saját maga is intézte több ízben a házasság felbontása céljából a magyar honpolgárságot szerző osztrákok ügyeit, ${ }^{39}$ a következő eredményre jutott: „Ha az erdélyi reformátusoknakés unitáriusoknak tetşik, bontsák fel ott a Királyhágón túl házasságukat saját szájuk ize szerint. De maradjanak otthon és ne csináljanak az. elválásból világra szóló ü̃letet. A magyar igazságszolgáltatás jó hírneve követeli, hogy ezon botrányos állapotnak mihamarabb vége vettessék. A magyar felelös minisztériumnak. már régen köz̧be kellett volna lépni és ha nem meri rendeleti utón a kérdést elintézni, nyújtson be törvényjavaslatot, mely az erdélyi házassági biróságok területi hatáskörét és illetóségük körét meghatározza." "40

Sztehlo cikkére Kolosváry Sándor válaszolt a Protestáns Közlöny hasábjain. ${ }^{41}$ Ebben - a felháborodottságának hangot adó sorok után - elsőként azt szögezte le, hogy az erdélyi református házassági jog „egyoldalú folyamodásra indított válópert” nem ismert. A „per viam instantiae” házassági ügyek valójában nemperes ügyek voltak, habár helytelenül így nevezeték azokat.

A házassági válópernek előzetesen már az illetékes fórum előtt lezajlott és jogerőre emelkedett ítélete által véglegesen vagy időlegesen ,,seprataio a thoro et mensa” elválasztott református - vagy törvényes áttérés által azzá lett - házas fél, a jogerôs ítélet keltét követő hat hónap után „per viam instantiae" kérhette azt, hogy rá, mint református felekezethez tartozóra az ítéletben kimondott separatiót divortiumra változtassa a házassági törvényszék. A másik félre nézve a saját vallásának hitelvei alapján ítélkező fórum által hozott korábbi ítélet hatálya továbbra is fennállt.

Ha az alperesre vonatkozó, saját hitelvei szerint megalkotott ítéletet hazai bíróság hozta, akkor a hazai törvények, ha pedig osztrák bíróság mondta ki, akkor pedig a nemzetközi magánjog (ha erről szó lehet) szerint is tiszteletben kell tartani és nem lehet felülbírálni. Ugyanakkor az 1868. évi LIII. tc. 8. \-a alapján a szeparáció után református hitre áttért személy is követelheti, hogy az áttérés után minden cselekménye, saját hitvallása és az új egyházának törvényei szerint legyenek megítélve. $^{42}$

\footnotetext{
38 SZTEHLO, Az erdélyi házasságról 1.

${ }^{39}$ NAGY, Budapesti válások - Kolozsváron 172.

40 SzTEHLO, Az erdélyi házasságról 1.

${ }^{41}$ KOLOSVÁRY, Jogos védelem 44-46.

${ }^{42}$ KOLOSVÁRY, Jogos védelem 45.
} 
A „per viam instantiae” eljárásban egy másik felekezet által hozott jogerős ítélet keltétôl a megbánás, kibékülés lehetőségére adott hat hónapos határidő csak az egyik feltételt képezte. Ugyanilyen jelentôs megkötésnek tartotta Kolosváry a hatáskörre és az illetékességre vonatkozó szabályokat, amelyek alapja II. Jórsef Házassági pátensének a kihirdetés feltételeire vonatkozó rendelkezései voltak, ${ }^{43}$ és ezt az addigra éppen egy évszázados gyakorlatot a vegyes házassági válóperekről szóló 1868. évi XLVIII. törvénycikk sem változtatta meg.

A domicilium igazolására nemcsak egyházi, hanem a polgári hatóság (szolgabíró, polgármester) által kiállított bizonyítvány bemutatása is szükséges volt, amely igazolta, hogy a folyamodót valamelyik községbe vagy városba felvették és az adott településen adózó magyar állampolgárnak minősül.

Szigorítást vezetett be a református Házassági Főtörvényszék, amikor döntvényileg rögzítették, hogy az idegen házassági ügyét - ha csak közhitelességi okmányokkal bizonyítani nem tudja, hogy magyar állampolgárságot nyert, vagy saját korábbi állampolgársága nem szűnt meg, akkor a magyar állampolgárság megszerzéséről és elvesztéséről szóló 1879. évi L. törvény miatt semmiképpen nem fogadja be a református ítélkezési fórum.

Ilyen, Pozsony város által 1885. augusztus 7-én kiállított honosítási igazolást nyújtott be például gróf Laval Nugent császári és királyi kamarás, aki sikeresen kérelmezte saját személyére nézve a magyar állampolgárságot. ${ }^{44} 1885$. május 7 -én a gyalui albíró állított ki igazolást („Felső Döblingbe” címezve), ami ekként fogalmazott: „[...] miszerint tekintve bemutatott erkölcsi, vagyoni és osz̨trák állami kötelékboöl kilépési bizonyitványát, elhatároztuk. Önt községünk tagjául ennek kötelékébe fölvenni, minek biztositására Önnek a sqokásos fölvételi dij már teljesitett befizetésének egyúttal való igazolása mellett ezennel kiadjuk az elöljáróság alárásával és helységünk pecsétjével ellátott jelen levelünket”." ${ }^{5}$

Az állampolgárságon kívül - az előbb említettek szerint - azt is igazolni kellett, hogy az adott személy az egyházmegye területén él és az adott község gyülekezetének a tagja. Erre azért volt szükség, mert abban az egyházmegyében lehetett megindítani az eljárást, ahol az alperes legalább hat hete lakott. ${ }^{46} \mathrm{Az}$ Utasítás egyik fordulata úgy szólt, hogy áttérési bizonyítvány mellett azt is bizonyítani kellett, hogy minden olyan kötelezettséget teljesítettek, amit az egyház kötelékébe tartozóknak kellett. ${ }^{47}$

Az 1888-as egyházi törvények 15. \-a a részletszabályokat is rögzítette. Magyarországnak minden református vallású lakosát és honpolgárát azon egyházközség rendes tagjának kellett tekinteni, ahol a polgári községnek is tagja volt, tehát az egyházi illetékesség jelentős mértékben támaszkodott a világira. Abban az esetben, ha az adott településen nem volt református egyházközség, akkor annak a kálvinista egyházközségnek a tagja lett, amelynek területéhez lakóhelyét az egyházmegyei vagy az egyházkerületi hatóság beosztotta. Ha valamelyik egyháztag az illetékes egyházközségen kívüli más egyházközségekben is rendesen és állandóan viselte az egyházi terheket, akkor ott is gyakorolhatta az egyháztagokat illető jogokat. ${ }^{48}$

\footnotetext{
${ }^{43}$ J. R. 32. S.

44 EREL, B1. A1/135.

${ }^{45}$ EREL, B1. A1/127. Ilyen levelet adtak még ki: A1/128.

46 1.-1882. H. F. Sz. Utasítás, 16. 』 Lásd: 5.1. fejezet.

47 1.-1882. H. F. Sz. Utasítás, 74. \.

${ }^{48} \mathrm{Az}$ erdélyi ev. ref. egyházkerület egyházi törvényeinek és szabályrendeleteinek Tára. I. kötet, az Erdélyi ev. ref. egyházkerület törvényei. Kolozsvár 1888. (a továbbiakban: 1888-as törvénygyüjtemény) 16. \$.
} 
Abban az esetben, ha valaki az egyházközségből egy másikba költözött, akkor hat heti ottlakást követően gyakorolhatta az egyházközségi tagságból fakadó jogokat és kellett viselnie az ezzel járó kötelességeket. Az 1888-as egyházi törvénymű 18. \-a azt is rögzítette, hogy az egyháztagok jogai közé tartozott többek között az is, hogy vallásügyi jogaik sérelme esetén fokozatosan - az egyházhatóságok védelmével éljenek. ${ }^{49}$

Az erről szóló igazolás a gyakorlatban egy rövid kötelező formai vagy tartalmi elemek nélküli bizonyítványt jelentett. Ilyen egyházi igazolást kapott Bilgeri Georgina asszony, amiben csupán annyit jegyzett meg a kiállító lelkész, hogy „mindennemú egybázi kötelességének eleget tett." ${ }^{50}$

Kolosváry elismerte: gyakori jelenség, hogy a házasság felbontását követően az adott személy visszatér a korábbi hazájába, de tagadja, hogy ez az egyház felelőssége lenne.

Kolosváry elutasította Sztehlo perköltségre vonatkozó vádjait, és kijelentette, hogy a házassági törvényszékek előtti eljárás során kiszabott díjakat az egyházi jog szabályai szerint határozzák meg, „kialkudott” díjak nincsenek. Az alszékek évente háromszor, a főtörvényszék pedig az Egyházkerületi Közgyưlés alkalmával évente egyszer tartott rendes ülést. A rendes ülésen történő ítélkezés (eltekintve a kereset, az okmányok, a tanúkihallgatás és az ítélet bélyegköltségeitől) az első és másodfok egyaránt 8-8 forint volt.

Ha valaki ügyének elbírálása érdekében rendkívüli házassági törvényszéki ülést hívott össze, akkor az egyházmegyében szétszórtan lakó bírák utazási költségét és „fáradságát” is meg kellett fizetni legfeljebb 100 forint összegig.

A rendkívüli ülés összehívása csak lehetőség volt, senki számára nem lehetett kötelezôvé tenni. Ha valamelyik peres fél mégis össze akarta hívatni a rendkívüli Házassági Fôtörvényszéket, akkor ki kellett fizetnie a bírák útiköltségét, mert a tagoknak „Szilágytól elkęquve föl Háromszékemegyéig” terjedő területről kellett összegyúlniük, és ezért 500 forintot kellett fizetni.

Kolosváry azzal zárja le a vitát, hogy „az ügyvédek esetleges visszaélése, nem az egyháqkerület visszaélése. A törvényszerü eljárás nem önkényes eljárás. Az orsz[ágos] törvény által biztositott hatalommal való élés nem visszaélée". ${ }^{1}$

Schmidt Magdaléna gyalui lakos beadványát 1885. május 12-én tárgyalta a kolozs-kalotai házassági törvényszék. A kérelem tanúsága szerint a währingi császári és királyi törvényszék 1877 ben kelt ítélete a katolikus férjétől szeparálta az asszonyt, és ezt az ítéletet kívánta most divortiumá változtatni. Az eredeti ítélet mellett még - annak rendje szerint - csatolta az áttérési bizonyítványt és egy hivatalos igazolást is arról, hogy az osztrák állampolgárságát elvesztette, valamint hogy Gyalu községbe felvették, valamint egy nyugtát is az egyháznak megfizetett adókról.

Ezek alapján a következőképpen indokolta az eljáró fórum a döntést: „[b]ázassági törvényszékeünk a bényúitott okmányok alapján meggyözoódött, hogy kérelmes Schmidt Magdolna, sұül Koczekek gyalui lakos, ev. ref. hitvallású és rovátát fizetö rendes tag: teljesen minösitettnek. kellett öt tartani arra, hogy mindazon jogokkal élhessen, melyeket erdélyi ev. ref. anyaszentegyházunk autonóm törvényei bitsorsosaink számára bižtositanak; ennél fogva belyet kellett, hogy adjon kérelmes folyamodásánake és ki kellett hogy mondja a fenn irt

\footnotetext{
49 1888-as törvénygyújtemény, 17. \.

${ }^{50}$ EREL, B1. A1/127. Ehhez lásd még: A1/126., A1/128., A1/129.

${ }^{51}$ KOLOSvÁrY, Jogos védelem 45.
} 
itéletet." Erre alapozva tehát a separatio a thoro et mensa ítéletet a Házassági törvény rajz 118-120. \$ alapján divortiumra változtatták. ${ }^{52}$

Meglehetősen bonyolult, több ország jogát érintő procedúra volt Nugent Laval bontópere gróf Pallavicini Máriával. A görczi császári és királyi törvényszék mint illetékes fórum 1884. május 31-én ítélte a feleket ágytól és asztaltóli elválasztásra. Az eljárás alapjaként szolgáló ítéletlevél eredetileg olasz nyelven kelt, ezt azonban idővel le kellett fordíttatnia németre is. Ezt követôen a felperes férj 1885. augusztus 13-án Bécsben áttért a református vallásra. ${ }^{53}$ Valószínúleg a minél gyorsabb eljárás érdekében a felepres férj párhuzamosan intézte az egyes ügyeket, így lehetséges, hogy már a magyar honosítási okiratot 1885. augusztus 7-én kiadták. Ebből az derül ki, hogy Nugent Arthur horvátországi nagybirtokos és magyarországi főrendi házi tag, aki egyben pozsonyi lakos is, örökbe fogadta a felperest, és a Sopron megyei Csorna község felvette kötelékébe. Az okirat ezt követően már úgy mutatja be gróf Nugent Lavalt mint nejétől elvált 42 éves császári királyi kamarást, pozsonyi lakost, aki a magyar állampolgárság megszerzéséről és elvesztéséről szóló 1879. évi L. törvény értelmében kérelmezte saját személyére nézve a magyar állampolgárságot, amelyet meg is kapott. A dokumentum figyelmeztette tulajdonosát, hogy a törvényben előírt állampolgári esküt a letételére felszólító idézés kézbesítésétől számítva egy éven belül le kell tenni, különben az okirat hatályát veszti.

A honosítási okirat fogalmazója azt is feljegyezte, hogy a Nugent Lavalnak három kiskorú gyermeke van, és apjuk kívánságára, valamint a császári és királyi hivatal kijelentése szerint egyelőre továbbra is osztrák állampolgárok maradtak. Pontosan egy hónappal később, augusztus 14-én a gróf le is tette az esküt. ${ }^{54} \mathrm{Az}$ igazolást, amely szerint minden anyagi kötelességének eleget tett, szeptember 2-án állította ki a gyalui lelkész. ${ }^{55}$ Ezt követően pedig 1885. szeptember 5-én már mint a Gyalu községi református ember kérte a separatio divortiummá változtatását. ${ }^{56}$

\section{4. Összegzés}

A magyar házassági jogok a 19. század második felére szinte áttekinthetetlen rendszert alkottak. A többféle felekezeti jog egymás melletti múködését a területileg eltérő szabályozás tovább bonyolította, amely visszaélésre adott lehetôséget. Az évtizedekig fennálló helyzetre reagált az erdélyi református Házassági Főtörvényszék, amikor szabályozta a „per viam instantiae” eljárásokat, amely a legvitatottabb jogintézménnyé vált. Ennek keretében a más felekezetről áttért személy vagy házaspár kérhette házassága felbontását, amennyiben a felek igazolni tudták az erdélyi lakóhelyüket. Mind a magyarországi, mind más osztrák tartományok hatóságai, de még az erdélyi református egyház között is feszültséget generált a téma. Az olykor vitákat kiváltó jelenség hátterében valójában a (nemzetközi) kollíziós magánjogi viszonyokból eredô sajátos probléma állt. Az Osztrák-Magyar Monarchia számos magánjogi rendszert magában foglaló közjogi keretei között felmerülő kérdést

\footnotetext{
${ }^{52}$ EREL, B1. A1/129. Ítélet, 1885. május 12. 1-2.

${ }^{53}$ EREL, B1. A1/135. Übertritts-Schein Wiener evangelischen Pfarrgemeinde helvetischen Confession, 1885. augusztus 13.

${ }^{54}$ EREL, B1. A1/135. Honosítási okirat, 1885. augusztus 7. 1-2.

${ }^{55}$ EREL, B1. A1/135. Bizonyítvány, 1885. szeptember 2.

${ }^{56}$ EREL, B1. A1/135. Beadvány, 1885. szeptember 5.
} 
végül - a Magyar Királyság területén - a házassági jogot egységesítő 1894. évi XXXI. törvény tudta csak feloldani.

Jelen tanulmányban arra törekedtem, hogy az erdélyi református egyház szabályozási kereteit bemutassam, és elsőként kövessem nyomon a tárgybeli belső egyházjogi diskurzust. Az errôl a kérdésről szóló eddig megjelent tudományos művek - néhány az elmúlt években megjelent kivételtôl eltekintve - fôként az erdélyi viszonyokat felületesen ismerő, korabeli magyarországi és osztrák szakirodalomból merítettek, amelyek még a számszerū adatok kritikus vizsgálata mellett is megőrizték a szemléletbeli alapállást.

Ez a társadalomtörténeti terminológia alapján válási migrációnak nevezett jelenség és a mögötte meghúzódó kollíziós magánjogi probléma jogtörténeti vizsgálata fontos jövőbeli kutatási témaként kínálkozik.

\section{Felhasznált források és irodalom}

1.-1882. H. F. Sz. Utasítás a házassági válóügyek ellátására nézve az erdélyi evang. reform. egyházkerületben 1879. évi L. törvénycikk a magyar állampolgárság megszerzéséről és elvesztéséről

1881. évi LX. törvénycikk a végrehajtási eljárásról

APEL, Angela: Die Siebenbürgischer und die Ungarischen Ehehen. Wien 1999

Az erdélyi ev. ref. egyházkerület egyházi törvényeinek és szabályrendeleteinek Tára. I. kötet, az Erdélyi ev. ref. egyházkerület törvényei. Kolozsvár 1888

Az erdélyi ev. ref. egyházkerület Marosvásárhelytt 1873. November 3-án 4-én 5-én 6-án 7-én 8-án 11-én 12-én tartott Házassági fötörvényszékének Jegyzőkönyve

BARCZA Kálmán: Házassági jogeset. Jogtudományi Közlöny 1879/41.

Die siebenbürgischen Ehen. Neue Freie Presse, 1885. szeptember 3. reggeli sz.

Erdélyi Protestáns Közlöny, 1877/44. sz.

Erdélyi Református Egyházkerületi Levéltár [EREL], A részleg: Az országos református intézmények levéltárai: A1. Az Erdélyi Református Egyházkerület (Állandó) Igazgatótanácsának Ülésjegyzőkönyvei 1868-1895; B1. Kalotaszegi (Kolozs-Kalotai) Egyházmegye Levéltára.

FUCHS, Wilhelm: Die sogenannten siebenbürgischen Ehen und andere Arten der Wiederverehelichung geschiedener österreichischer Katholiken. Wien 1889

HARMAT, Ulrike: Ehe auf Widerruf? Der Konflikt um das Eherecht in Österreich 1919-1938. Frankfurt am Main 1999

HERGER Csabáné: A nővételtől az állami anyakönyvvezetőig. Budapest-Pécs 2006

J. R. = II. Jósefnek házassági rendelései melyek 1786-dik Eszt. Mártius 6-kán tétettek, és Magyarországban Az 1791 beli Diaetának 26-dik Czikkelye által megerössíttettek. In.: BOD Péter: Házassági törvény rajz vagy a házassági törvényekrôl való tanítás, melyben a' mátkaság, megmásolás és elválás körülti házassági különbféle esetek felhozatnak, megvizsgáltatnak, és a' tudósok véleményeikből, közönséges zsinatok folytáikból és végzéseikből meghatároztatnak (ford., bőv., kiad.: BENKŐ László). Kolozsvár 1836

KOLOSVÁRY Sándor: Jogos védelem. Protestáns Közlöny 1886/5. sz.

MEILI, Friedrich: Geschichte und System des internationalen Privatrechts im Grundriss. Leipzig 1892

NAGY Péter: Erdélyi református házassági bíráskodás a Házassági Főtörvényszék fennállása idején. Budapest 2021.

NAGY Sándor: „Engesztelhetetlen gyülölet” Válás Budapesten (1850-1914). Budapest 2018

NAGY Sándor: Budapesti válások - Kolozsváron, 1869-1895. A budapesti és a fôvárosi migráns válóperes felek joghasználatának, csoportjellemzőinek vizsgálata. Fons 2010/2. sz.

NAGY Sándor: Egy birodalom, két állam, sokféle törvény. Házassági jog és válás az Osztrák-Magyar Monarchiában. Fons 2014/4. sz. 
NAGY, Sándor: Österreichische Scheidungen in Klausenburg (1868-1895) Otto Wagners „Siebenbürger Ehe”. In: FISCHER, Karl (Hrsg.): Jahrbuch des Vereins für Geschichte der Stadt Wien. Band 69/71. Wien 2018

NeschWARA, Christian: Eherecht und „Scheinmigration” im 19. Jahrhundert: Siebenbürgische und ungarische, deutsche und Coburger Ehen. BRGÖ 2012/2.

Osztrák Általános Polgári Törvénykönyv. In: HALLER Károly: Az általános polgári törvénykönyv, mint ez jelenleg Erdélyben érvényes minden a legujabb időig megjelent és még hatályban levő utólagos rendeletekkel, felvilágosító és utasító jegyzetekkel ellátva. Kolozsvár 1865

PELIKAN, Christa: Aspekte der Geschichte des Eherechtes in Österreich. Wien 1981

SzTEHLO Kornél: Az erdélyi házasságról. Pesti Napló 1886/16. sz. reggeli kiadás

SzTEHLO Kornél: Az erdélyi házasságról. Ügyvédek Lapja 1886/4. sz.

VARGA Norbert: A magyar állampolgársági jog a 19. században. Budapest 2012 